\title{
Methane emissions and estimates of ruminal fermentation parameters in beef cattle fed different dietary concentrate levels
}

\author{
Márcio dos Santos Pedreira1, Simone Gisele de Oliveira², Odo Primavesi ${ }^{3}$, Magda Aparecida \\ de Lima ${ }^{4}$, Rosa Toyoko Shiraishi Frighetto ${ }^{4}$, Telma Teresinha Berchielli ${ }^{5}$
}

\footnotetext{
1 Universidade Estadual do Sudoete da Bahia.

2 Universidade Federal do Paraná.

${ }^{3}$ Centro de Pesquisa de Pecuária do Sudeste - EMBRAPA.

${ }^{4}$ Centro Nacional de Pesquisas em Meio Ambiente - EMBRAPA

${ }^{5}$ Faculdade de Ciências Agrárias e Veterinárias - Unesp.
}

\begin{abstract}
Using sorghum silage, the effect of roughage/concentrate ratios was evaluated on nutrient intake, digestibility, ruminal parameters and methane production by beef cattle. Three treatments $(0,30$ and $60 \%$ of concentrate in DM of the diet) were distributed in three Latin squares, with nine animals and three periods. Dry matter intake increased as the grain concentration in diet increased; $\mathrm{pH}$ showed opposite behavior. Methane emissions were lower for animals fed the diet exclusively with sorghum silage as compared with those fed $30 \%$ of concentrate, but was similar to that of animals receiving $60 \%$ of concentrate. Losses of ingested gross energy as methane were reduced by $33 \%$ when grain concentration was increased in the diet. Concentrations of propionic and butyric acids were greater in diets with grain concentrate; acetic acid concentration was not affected. Concentrate in diet increases available energy for the metabolism, measured by lower losses of ingested gross energy as ruminal methane.
\end{abstract}

Key Words: global greenhouse gases, nutritional value, rumen fermentation, $\mathrm{SF}_{6}$

\section{Introduction}

Measurements of ruminal methane emissions are of great importance since they allow for the quantification of two important aspects: greenhouse gas emissions and ingested energy losses by ruminants (Animut et al., 2008).

Ruminal fermentation processes are affected by the interaction of a great number of factors, such as chemical and physical quality of the feed, feed intake, end products of fermentation, indigestible residues and ruminal nutrient flow. These factors will affect types and activities of ruminal populations of methanogenic microorganisms.

Plant cell-wall components are more methanogenic than the carbohydrate of inner cell contents (Johnson \& Johnson, 1995). Therefore, the methane production mechanism may be affected by the amount of fermented organic matter in the rumen and the type of carbohydrate in the diet. Forage intake results in production of ruminal methane, which is increased with addition of digestible organic matter until ruminal $\mathrm{pH}$ becomes inhibitory to microbial growth or when the passage rate increases, reducing the fermentation degree of feed in rumen. GigerReverdin \& Sauvant (2000) observed a quadratic result in methane production with the increase of grain in the diet for sheep, where maximum methane emissions occurred between 30 and $40 \%$ of grain concentrate. Greater grain amounts reduced methane production, indicating possible changes in ruminal environmental characteristics, as well as in feed permanence in the rumen, affecting methanegenesis (Matsuyama et al., 2000).

The objective of this study was to evaluate the influence of sorghum silage diets with different grain concentrate levels on ruminal parameters, nutrient intake and digestibility and methane production by beef cattle with indirect measurement.

\section{Material and Methods}

Nine cannulated crossbred steers $(444 \pm 30 \mathrm{~kg})$ fitted with a permanent ruminal fistula and duodenal Y-cannula, with a surgical recovery time of two years were used. The experiment comprised three periods of 15 days. The first ten days were used for animal adaptation to diets, and the last five days for the ruminal gas collection, using an experimental protocol adapted from $\mathrm{Fu}$ et al. (2001). During the experimental period, animals stayed in individual pens with individual bunks and automatic water dispensers. 
Diets were composed of different roughage/grain concentrate ratios (Table 1).

The hybrid sorghum variety used was sorghum BR 700, produced by EMPRAPA (Sete Lagoas, MG, Brazil). Treatments were $100 \%$ of roughage in DM of the diet without concentrate (0); $70 \%$ roughage plus $30 \%$ concentrate in DM (30); and $40 \%$ roughage plus $60 \%$ concentrate in DM (60). Diets were supplied once a day and orts were weighed for calculation of dry matter and nutrient intake.

Duodenal flow of the digesta was determined by collecting $500 \mathrm{~mL}$ of duodenal contents during the 2 nd day at $03 \mathrm{~h} 00$ and $09 \mathrm{~h} 00$ and $15 \mathrm{~h} 00$ and $21 \mathrm{~h} 00$ and during the 3 rd day at $00: 00,06 \mathrm{~h} 00$ and $12 \mathrm{~h} 00$ and $18 \mathrm{~h} 00$ and $24 \mathrm{~h} 00$ after feeding. Samples were kept at $-10{ }^{\circ} \mathrm{C}$, and at the end of the period, a composite sample was prepared for each duodenal sampling for each animal within each period. The internal marker indigestible neutral detergent fiber (iNDF) was used to estimate the duodenal flow. The iNDF was obtained after 144 hours of incubation in the rumen (Krysl et al., 1988; Berchielli et al., 2005); each diet was analyzed for the marker content. For the duodenal flow estimates, the following equation was used:

Duodenal flow $(\mathrm{g} /$ day $)=$ Fecal production $(\mathrm{g}) \times($ iNDF in feces $(\mathrm{g} / \mathrm{kg}) / \mathrm{iNDF}$ in duodenal digesta $(\mathrm{g} / \mathrm{kg}))$

Fecal samples were collected twice a day (at 07h30 and 19h30) during five consecutive days (ten samples per animal) to calculate daily fecal production. Samples were subsequently frozen. At the end of the experimental period samples for each animal were gathered and thawed and dried at $55^{\circ} \mathrm{C}$ for 72 hours. Fecal production was estimated using indigestible neutral detergent fiber (iNDF) as internal marker (Krysl et al., 1988; Berchielli et al., 2005). For the

Table 1 - Proportion of ingredients and chemical composition of experimental diets on a dry matter (DM) basis

\begin{tabular}{lccc}
\hline \multirow{2}{*}{ Ingredients } & \multicolumn{3}{c}{ Concentrate level in diet (\%) } \\
\cline { 2 - 4 } & 0 & 30 & 60 \\
\hline Sorghum silage & 100 & 70 & 40 \\
Corn & - & 27 & 54 \\
Soybean meal & - & 3 & 6 \\
Chemical composition (\% DM) & & & \\
DM (\%) & 35.5 & 51.1 & 66.8 \\
In \% DM & & & \\
Organic matter & 93.6 & 91.9 & 90.1 \\
Crude protein & 5.4 & 7.5 & 9.6 \\
Neutral detergent fiber & 70.1 & 55.9 & 41.8 \\
Acid detergent fiber & 40.2 & 29.5 & 18.7 \\
ADIN/N (g/kg N) & 34.9 & 25.2 & 15.4 \\
Gross energy (kcal/kg DM) & 4290 & 4433 & 4577 \\
\hline
\end{tabular}

0 - no concentrate; $30-30 \%$ of concentrate in DM of the diet; $60-60 \%$ of concentrate in $\mathrm{DM}$ of the diet.

ADIN/N - acid detergent insoluble nitrogen. fecal production estimates, the following equation was used:

\section{Fecal production $(\mathrm{g} / \mathrm{d})=$ Marker ingested $(\mathrm{g}) /$ \\ Concentration of marker in feces $(\mathrm{g} / \mathrm{kg})$}

The samples of feed, orts, duodenal digesta and feces were dried in a forced ventilation oven at $55{ }^{\circ} \mathrm{C}$ for 72 hours and ground in a Wiley mill (Arthur H. Thomas Co., Philadelphia, PA, USA) through a $1 \mathrm{~mm}$ screen to determine $\mathrm{DM}$ by drying at $105{ }^{\circ} \mathrm{C}$ for 12 hours in a forced air oven, and ash and $\mathrm{N}$ content according to methods 942.04 and 976.05 of AOAC, respectively (1990). The samples were also analyzed for neutral detergent fiber (NDF) corrected for ash, acid detergent fiber (ADF) and lignin according to methodologies adapted from Van Soest et al. (1991). Heatstable amylase (Termamyl 2x) and sodium sulphite were used in the NDF procedure. Nitrogen concentration in the residues of NDF and ADF analyses were also determined to estimate the fiber-bound nitrogen. Gross energy (GE) was determined by total combustion of the sample using a bomb calorimeter (Parr Instrument Co., model 1261, Moline, IL, USA).

Samples of ruminal content were collected on the fourth day of each experimental period to determine the concentration of volatile fatty acids (acetic, propionic, and butyric), ammonium nitrogen and $\mathrm{pH}$ value. Samples were collected at $0,2,4,8,12$ and 24 hours after feeding and filtered, and ruminal $\mathrm{pH}$ was measured with a $\mathrm{pH}$ meter (Accumet, model HP-71, Fisher Scientific, Pittsburgh, PA, USA). Two samples were stored and frozen at $-10{ }^{\circ} \mathrm{C}$, the first being acidified with $1 \mathrm{~mL}$ of chloridic acid at a concentration of $2 \mathrm{~mL} / \mathrm{L}$ to analyze ammonia nitrogen $\left(\mathrm{NH}_{3}-\mathrm{N}\right)$, according to Chaney \& Marbach (1962), and the second was acidified with metaphosphoric acid to determine the concentration of short-chain fatty acids (SCFA) (Leventini et al., 1990).

Eructated methane was sampled per animal during five consecutive days. The sulphur hexafluoride $\left(\mathrm{SF}_{6}\right)$ tracer gas method was used to collect and estimate methane emissions (Westberg et al., 1988; Johnson et al., 1994; Primavesi et al., 2004). Methane and $\mathrm{SF}_{6}$ concentration readings were performed using a gas chromatograph (Hewlett Packard, Model HP 6890, Ramsey, MN, USA).

The experiment was conducted in three Latin squares $(3 \times 3)$, shot simultaneously in three periods, using nine animals, three per square, with three treatments $(0,30$ and $60 \%$ concentrate in dietary DM). Data were subjected to a Mixed Procedure analysis (Littell et al., 1996) of SAS (Statistical Analysis System, version 8.2). The lowest setting Akaike information criterion (AIC) was obtained using the variance component (CS). Treatment effects 
were decomposed into linear and quadratic polynomial regression and differences between means were tested using orthogonal contrasts at a significance level of $5 \%$.

$$
\mathrm{Y}_{\mathrm{ijkm}}=\mu+\mathrm{Q}_{1}+\mathrm{P}_{\mathrm{i}}+\mathrm{A}_{\mathrm{j}}\left(\mathrm{Q}_{1}\right)+\operatorname{Tr}_{1}+\varepsilon_{\mathrm{ijk}} ; \mathrm{NID}\left(0 ; \sigma^{2}\right)
$$

where: $\mu=$ overall mean; $Q_{1}=$ effect of Latin squares $(1=1$ to 3$) ; \mathrm{P}=$ effect of period ( $\mathrm{i}=1$ to 3$) ; \mathrm{A}_{\mathrm{j}}\left(\mathrm{Q}_{1}\right)=$ animal effect within the square $(j=1$ to 9$)$; $\operatorname{Tr}=$ concentrate levels $(0,30$ and $60 \%$ ); and $\varepsilon_{\mathrm{ijk}}=$ random error.

\section{Results}

Inclusion of concentrate in diet increased DM intake by animals (Table 2 ).

Observed values of dry mater intake were 5.5, 7.9 and $8.7 \mathrm{~kg} / \mathrm{d}$ for animals ingesting 0,30 and $60 \%$ of concentrate in DM of the diet, respectively. Organic mater and gross energy intakes were also different between treatments, increasing along with the concentrate inclusion in diets.

Neutral detergent fiber intake showed a quadratic behavior; it was higher in treatments with $30 \%$ of concentrate $(4.10 \mathrm{~kg} / \mathrm{d})$ than in diets without it, and with $60 \%$ of concentrate, respectively, with 3.6 and $3.3 \mathrm{~kg} / \mathrm{d}$. Treatments 0 and $60 \%$ were not different.
Dry matter and and OM digestibility (Table 3) were only different between the 0 and $60 \%$ concentrate diet, with no differences between 0 and $30 \%$ of concentrate. Measured values for apparent whole tract (total) digestibility of DM were 50.7 and $62.3 \%$ of DM for diets with 0 and $60 \%$ of concentrate, respectively; for $\mathrm{OM}$, they were 53.7 and $63.9 \%$ of DM.

Total apparent digestibility of NDF was not influenced by concentrate levels in the diet, with a mean value of 45.0\%. Dietary concentrate levels also did not influence the digestibility of DM, OM, NDF and GE in the rumen. For OM and NDF, the mean values of ruminal digestibility were, respectively, 37.4 and $45.8 \%$.

Ruminal $\mathrm{pH}$ showed a negative linear behavior with inclusion of concentrate in the diet (Table 4).

Ammonia nitrogen $\left(\mathrm{NH}_{3}-\mathrm{N}\right)$ did also differ between treatments, increasing linearly up to the $60 \%$ concentrate level in diet. Concentrations of short-chain fatty acids (SCFA) in ruminal fluid were different for total propionate $(\mathrm{P})$ and butyrate (B). Concentrations of these acids increased with greater concentrate content in diets, but with no difference between $30 \%$ and $60 \%$ of concentrate. Concentrations of acetic acid (A) were not influenced by treatments.

Table 2 - Dry matter and nutrient intake by beef cattle as a function of concentrate level in the diet

\begin{tabular}{|c|c|c|c|c|c|c|c|c|c|}
\hline \multirow{2}{*}{ Items } & \multicolumn{3}{|c|}{ Concentrate level in diet (\%) } & \multirow{2}{*}{ SEM } & \multicolumn{3}{|c|}{ Contrast } & \multicolumn{2}{|c|}{ P-value } \\
\hline & 0 & 30 & 60 & & $0 v s .30$ & $0 v s .60$ & 30 vs. 60 & Linear & Quadratic \\
\hline \multicolumn{10}{|l|}{ Intake $(\mathrm{kg} / \mathrm{d})$} \\
\hline Dry matter & 5.5 & 7.9 & 8.7 & 0.281 & 0.004 & 0.002 & 0.028 & 0.002 & 0.019 \\
\hline Organic matter & 5.2 & 7.5 & 8.3 & 0.274 & 0.002 & 0.006 & 0.037 & $<0.001$ & 0.029 \\
\hline Neutral detergent fiber & 3.6 & 4.1 & 3.3 & 0.080 & 0.074 & 0.192 & 0.020 & 0.192 & 0.025 \\
\hline Gross energy (Mcal/d) & 23.8 & 35.4 & 40.1 & 1.394 & $<0.001$ & $<0.001$ & 0.004 & $<0.001$ & 0.005 \\
\hline
\end{tabular}

0 - no concentrate; $30-30 \%$ of concentrate in DM of the diet; $60-60 \%$ of concentrate in DM of the diet.

SEM - standard error of the mean.

Table 3 - Total tract and ruminal apparent digestibility in cattle as a function of concentrate level in diet

\begin{tabular}{|c|c|c|c|c|c|c|c|c|c|}
\hline \multirow{2}{*}{ Items } & \multicolumn{3}{|c|}{ Concentrate level in diet (\%) } & \multirow{2}{*}{ SEM } & \multicolumn{3}{|c|}{ Contrast } & \multicolumn{2}{|c|}{ P-value } \\
\hline & 0 & 30 & 60 & & $0 v s .30$ & 0 vs. 60 & 30 vs. 60 & Linear & Quadratic \\
\hline \multicolumn{10}{|c|}{ Total tract apparent digestibility (\%) } \\
\hline Dry matter & 50.7 & 55.7 & 62.3 & 1.608 & 0.238 & 0.036 & 0.142 & 0.036 & 0.804 \\
\hline Organic matter & 53.7 & 58.0 & 63.9 & 1.554 & 0.188 & 0.032 & 0.157 & 0.032 & 0.929 \\
\hline Neutral detergent fiber & 45.7 & 43.2 & 46.2 & 1.761 & 0.330 & 0.063 & 0.209 & 0.063 & 0.830 \\
\hline Gross energy & 52.5 & 56.3 & 62.9 & 1.672 & 0.499 & 0.886 & 0.422 & 0.886 & 0.399 \\
\hline \multicolumn{10}{|c|}{ Ruminal apparent digestibility (\%) } \\
\hline Dry matter & 26.2 & 27.6 & 34.1 & 2.280 & 0.872 & 0.305 & 0.253 & 0.305 & 0.427 \\
\hline Organic matter & 38.6 & 34.6 & 38.9 & 2.326 & 0.526 & 0.967 & 0.502 & 0.967 & 0.456 \\
\hline Neutral detergent fiber & 43.1 & 45.2 & 49.2 & 1.722 & 0.534 & 0.117 & 0.259 & 0.117 & 0.732 \\
\hline Gross energy & 34.6 & 33.0 & 39.1 & 2.392 & 0.779 & 0.461 & 0.333 & 0.461 & 0.462 \\
\hline \multicolumn{10}{|c|}{ Ruminal apparent digested matter $(\mathrm{kg} / \mathrm{d})$} \\
\hline Dry matter & 1.4 & 2.1 & 2.9 & 0.198 & 0.188 & 0.033 & 0.108 & 0.033 & 0.727 \\
\hline Organic matter & 2.0 & 2.6 & 3.2 & 0.185 & 0.173 & 0.039 & 0.157 & 0.039 & 0.956 \\
\hline Neutral detergent fiber & 1.5 & 1.8 & 1.6 & 0.064 & 0.042 & 0.396 & 0.116 & 0.396 & 0.046 \\
\hline
\end{tabular}

0 - no concentrate; 30 - $30 \%$ of concentrate in DM of the diet; $60-60 \%$ of concentrate in DM of the diet.

SEM - standard error of the mean. 
Methane production as $\mathrm{g} / \mathrm{d}, \mathrm{Mcal} / \mathrm{d}$ and $\mathrm{g} / \mathrm{kg} \mathrm{LW}^{-0.75}$ (Table 5) had the same behavior related to the variation of concentrate in the diet. The higher daily methane production, with $30 \%$ of concentrate in DM of the diet $(149.9 \mathrm{~g} / \mathrm{d})$, compared with the treatments without concentrate $(125.2 \mathrm{~g} / \mathrm{d})$, suggests a relation with the amount of NDF digested in the rumen because of greater amounts of NDF degraded in the rumen (Table 3 ) resulting in greater methane production.

Methane yield as $\mathrm{g} / \mathrm{kg}$ rumen-degraded organic matter was not different between treatments, although a trend of reduction occurred with the inclusion of concentrate in the diet, from $62.6 \mathrm{~g}$ to $43.8 \mathrm{~g} / \mathrm{kg}$ rumen-degraded organic matter. This is a very important variation that might contribute to reduction in methane production as a percentage of gross energy intake.

\section{Discussion}

Values of DM intake (DMI) of animals fed only sorghum silage were greater than that recorded by Mizubuti et al. (2002), of about $4.7 \mathrm{~kg} / \mathrm{d}$ for bovines ingesting sorghum silage with $5.1 \%$ of $\mathrm{CP}$, considering an average live weight of $450 \mathrm{~kg}$. Inclusion of concentrate did increase $\mathrm{CP}$ and decrease NDF content in diet, which explains the increased dry mater intake.
Berchielli et al. (1996a) recorded data supporting the results of this work, in which DM intake increased from 4.5 to $5.3 \mathrm{~kg} / \mathrm{d}$ when concentrate in the diet was increased from 20 to $60 \%$ in DM of the diet. Intake of OM and GE also increased with greater amounts of concentrate in the diet, perhaps due to a greater DMI and concentration of these nutrients in the dietary dry matter.

Neutral detergent fiber intake showed a quadratic behavior, increasing up to $30 \%$ concentrate and decreasing after this point. Cardoso et al. (2000) recorded lower daily NDF consumption, of about 2.9 to $1.5 \mathrm{~kg} / \mathrm{d}$, increasing concentrate levels in the dietary DM from 20 to $75 \%$, as a consequence of the decrease in NDF in the diet.

Increase in $\mathrm{DM}$ and $\mathrm{OM}$ digestion could be a consequence of a greater concentration of total digestible carbohydrates in diets with $60 \%$ of concentrate, as compared with the greater total structural carbohydrate content in diets of sorghum silage without concentrate, besides the increased CP content, which may contribute to greater microbial activity efficiency in the rumen. This may also explain the increase of gross energy digestibility, from 52.5 to $62.9 \%$, with increasing concentrate levels in the diet.

The digested amounts of DM, OM and NDF in the rumen, as $\mathrm{kg} / \mathrm{d}$, reflected the variations of DM intake and the content of these nutrients in the diet. Digested amounts of organic matter in the rumen increased with growing levels

Table 4 - Ruminal parameters in cattle as a function of concentrate level in diet

\begin{tabular}{|c|c|c|c|c|c|c|c|c|c|}
\hline \multirow{2}{*}{ Items } & \multicolumn{3}{|c|}{ Concentrate level in diet $(\%)$} & \multirow{2}{*}{ SEM } & \multicolumn{3}{|c|}{ Contrast } & \multicolumn{2}{|c|}{ P-value } \\
\hline & 0 & 30 & 60 & & $0 v s .30$ & $0 v s .60$ & 30 vs. 60 & Linear & Quadratic \\
\hline $\mathrm{pH}$ & 6.9 & 6.7 & 6.4 & 0.051 & 0.046 & 0.005 & 0.113 & 0.005 & 0.717 \\
\hline NH3-N (mg/dL) & 3.1 & 4.2 & 6.7 & 0.447 & 0.479 & 0.039 & 0.109 & 0.039 & 0.541 \\
\hline Total SCFA & 80.4 & 93.6 & 97.9 & 2.437 & 0.130 & 0.088 & 0.450 & 0.088 & 0.389 \\
\hline Acetic acid & 60.9 & 68.9 & 68.9 & 0.531 & 0.250 & 0.249 & 0.992 & 0.249 & 0.398 \\
\hline Propionic acid & 13.6 & 16.8 & 19.3 & 0.333 & 0.015 & 0.002 & 0.029 & 0.003 & 0.618 \\
\hline
\end{tabular}

0 - no concentrate; $30-30 \%$ of concentrate in DM of the diet; $60-60 \%$ of concentrate in DM of the diet.

SCFA - short-chain fatty acid.

SEM - standard error of the mean.

Table 5 - Methane emissions and energy loss as methane by cattle as a function of concentrate level in diet

\begin{tabular}{|c|c|c|c|c|c|c|c|c|c|}
\hline \multirow{2}{*}{ Items } & \multicolumn{3}{|c|}{ Concentrate level in diet (\%) } & \multirow{2}{*}{ SEM } & \multicolumn{3}{|c|}{ Contrast } & \multicolumn{2}{|c|}{ P-value } \\
\hline & 0 & 30 & 60 & & $0 v s .30$ & $0 v s .60$ & $30 v s .60$ & Linear & Quadratic \\
\hline \multicolumn{10}{|c|}{ Methane emissions } \\
\hline $\mathrm{g} / \mathrm{d}$ & 125.2 & 149.9 & 140.4 & 3.466 & 0.044 & 0.150 & 0.327 & 0.150 & 0.082 \\
\hline $\mathrm{g} / \mathrm{d} / \mathrm{kg}^{-0.75}$ & 1.2 & 1.5 & 1.4 & 0.037 & 0.058 & 0.153 & 0.496 & 0.153 & 0.127 \\
\hline $\mathrm{Mcal} / \mathrm{d}$ & 1,6 & 2.0 & 1.8 & 0.045 & 0.045 & 0.152 & 0.327 & 0.152 & 0.082 \\
\hline $\mathrm{g} / \mathrm{kg} \mathrm{RDOM}$ & 62.7 & 57.6 & 43.9 & 1.089 & 0.402 & 0.250 & 0.707 & 0.250 & 0.773 \\
\hline $\mathrm{g} / \mathrm{kg}$ RDNDF & 83.5 & 83.3 & 87.8 & 4.808 & 0.706 & 0.938 & 0.651 & 0.938 & 0.633 \\
\hline \multicolumn{10}{|c|}{ Methane energy loss } \\
\hline GEI (\%) & 6.9 & 5.6 & 4.6 & 0.222 & 0.029 & 0.007 & 0.056 & 0.007 & 0.613 \\
\hline
\end{tabular}

0 - no concentrate; 30 - $30 \%$ of concentrate in DM of the diet; $60-60 \%$ of concentrate in DM of the diet.

RDOM - rumen-digested organic matter; RDNDF - rumen-digested neutral detergent fiber; GEI - gross energy intake.

SEM - standard error of the mean. 
of concentrate in the diet. Recorded values of digested NDF in the rumen were lower with the sorghum silage without concentrate $(1.5 \mathrm{~kg} / \mathrm{d})$ than diets with $30 \%$ of concentrate, with decreasing trend above this level. This behavior certainly influenced the ruminal methane production profile as a function of concentrate levels in the diet.

Increase in the concentration of propionic and butyric acids as a function of concentrate levels in the diet was also recorded by Berchielli at al. (1996b), although differences in acetic acid did not occur as a function of the treatments. When considering total SCFA, no differences were observed between diets, but there was a trend to increase $(\mathrm{P}=0.0881)$. These results are supported by the literature, which reports a variation in the concentration of total SCFA as a function of increasing concentrate levels in diets (Eun et al., 2004).

Koster et al. (1996) reported that animals fed concentrate presented a lower proportion of acetic acid than those fed only roughage. In vitro studies (Eun et al., 2004) have shown a linear increase of propionic and butyric acid concentrations and a decrease in the molar proportion of acetic acid after an increase of corn levels in gamagrass silage (Tripsacum dactyloides). Increases in the concentration of butyric acid may be related to the concentration of rumen protozoa. Huhtanen (1993) reported that the increase in number of protozoa is followed by an increase in butyric acid in the rumen. But if ruminal standards are changed significantly by inclusion of concentrate, mainly related to $\mathrm{pH}$, this association between butyric acid and protozoa may not be positive, due to the sensitivity of these microorganisms to a significant $\mathrm{pH}$ drop in the rumen (Dehority \& Orpin, 1988).

An increase in the concentrate level of the diet reduced the $\mathrm{pH}$ of ruminal fluid, indicating that the increase of substrate for microbial activity results in a greater ruminal fermentation activity, with the increase of $\mathrm{NH}_{3}-\mathrm{N}$ concentration and also the total amount of SCFA, which are mostly propionic and butyric acid. When used in roughage diets, fermentable carbohydrates reduce ruminal $\mathrm{pH}$, which reduces cellulolitic activity and limits fiber digestion (Eun et al., 2004). However, the inclusion of up to $600 \mathrm{~g} \mathrm{~kg}^{-1}$ of concentrate did not decrease the $\mathrm{pH}$ to a value critical enough to reduce cellulolitic activity. This is also corroborated by the maintenance of the NDF ruminal digestibility coefficient, with a tendency to increase with concentrate inclusion in the diet. Eun et al. (2004) reported that this may happen, in part, due to the buffer effect of activity of protozoa, which are present in large populations when the animals are fed grass silage.

These data may point to important conclusions. When the amount of concentrate increased to $60 \%$ dry matter, intake rised, but methane decreased, confirming that this is not an adequate way to predict methane production. Estimates of methane production have been made based on dry matter intake or total carbohydrate supplemented in the diets (Blaxtes \& Clapperton, 1965), but depends on the feeding level to which the animal is subjected. At the maintenence level of feeding the higher the apparent digestibility of a feed, the greater the $\mathrm{CH}_{4}$ production/100 kcal feed consumed. Doubling feed intake depressed $\mathrm{CH}_{4}$ production more with high- than low-quality materials (Blaxtes \& Clapperton, 1965). O'Hara et al. (2003) also corroborated this measurement of ruminal methane emissions by bovines. Moss et al. (1995) remarked the fact that ruminal methane production is directly related to DM consumption, but measurements need to be made without variations in the DM source, related mainly to fiber content and diet quality.

When methane production is evaluated with respect to the amount of nutrient intake, data show that the percentage of ingested gross energy converted to methane drops when the amount of roughage in the diet is reduced from 100 to $40 \%$ of DM, indicating a greater energetic efficiency of diets with the concentrate. In this study, recorded values were $6.9 \%$ of ingested gross energy for exclusive sorghum silage diets and $4.6 \%$ for diets with $60 \%$ of concentrate. The amount of ruminal methane produced depends on the quality of the diet ingested, and represents 2 to $12 \%$ of gross energy intake. Blaxtes \& Clapperton (1965) reported that, at maintenance-level feeding, $\mathrm{CH}_{4}$ losses were 6.7 and $9.3 \%$ of the energy ingested through feed with an apparent digestibility of 50 and $90 \%$, respectively. These results are consistent with those found by Oliveira et al. (2007) when the percentage of losses in relation to ingested GE was lower when concentrate was added to diet. For Latin America, where animals are most commonly fed fiber-rich diets, IPCC (2007) considered emissions values of about $6.5 \%$. Energy loss as methane by animals consuming sorghum silage with $5.4 \% \mathrm{CP}$ was similar to that considered by IPCC for Latin America, corroborating this estimate.

Johnson \& Johnson (2002) suggested that changes in the organic matter source, from fibrous to more digestible carbohydrates in the rumen, such as starch, will allow for lower methane production per fermented carbohydrate unit because the cell wall components are more methanegenic than the carbohydrate of the cell content. Beauchemin \& McGinn (2005) studied methane production in finishing beef cattle and recorded lower methane production in animals fed grain diets (corn). This behavior was also measured in this study, when roughage fiber was substituted by nonfibrous nutrients; methane production did reduce, although 
there was no change in methane production per ingested NDF unit in any of the treatments.

The amount of digested fiber in the rumen also influenced the concentration and molar proportions of fatty acids in the ruminal fluid, with an impact on methane production. When diets were exclusively composed of sorghum silage, ruminal methane production was lower than when $30 \%$ of concentrate was included in the diet, which is in line with the observations of Christophersen et al. (2008). This is partially explained by an increase in rumen-digested neutral detergent fiber (RDNDF) and also by a greater total concentration of SCFA in the ruminal fluid. In this case, the increase in molar proportions of propionic acid was not sufficient to compensate for the increase of free hydrogen in the ruminal environment, a product of dry matter fermentation, and a substract for methanegenesis. When concentrate levels increased to $60 \%$ of concentrate of DM of the diet, methane production had a trend to reduce, with two causes for this behavior: first, the increase of DMI was not followed by increase in RDNDF; and second, under this condition the molar proportion of propionic acid was improved, reducing the free hydrogen (as metabolic production of this acid captures hydrogen). The association of both factors may explain the greater energy use of the diet.

\section{Conclusions}

Concentrations of short-chain fatty acid vary according to the roughage/concentrate ratios of diets. Ruminal methane production is associated with ruminal apparent digested fiber and concentration, as well as molar proportion of volatile fatty acids in the ruminal fluid. The inclusion of concentrate in the diet increases the available energy for the metabolism, demonstrated by lower losses of ingested gross energy as methane.

\section{Acknowledgments}

The authors thank Centro Nacional de Pesquisa de Monitoramento e Avaliação de Impacto Ambiental from Empresa Brasileira de Pesquisa Agropecuária (EMBRAPACNPMA) for the methane and $\mathrm{SF}_{6}$ concentration readings.

\section{References}

ANIMUT, G.; PUCHALA, R.; GOETSCH, A.L. et al. Methane emissions by goats consuming diets with different levels of condensed tannins from lespedeza. Animal Feed Science and Technology, v.144, p.212-227, 2008.
ASSOCIATION OF OFFICIAL ANALYTICAL CHEMISTS AOAC. Official methods of analysis. 15.ed. Gaithersburg, MD: AOAC, 1990

BEAUCHEMIN, K.A.; McGINN, S.M. Methane emissionss from feedlot cattle fed barley or corn diets. Journal of Animal Science, v.83, p.653-661, 2005.

BERCHIELLI, T.T.; OLIVEIRA, S.G.; CARRILHO, E.N.V.M. et al. Comparação de marcadores para estimativas de produção fecal e de fluxo de digesta em bovinos. Revista Brasileira de Zootecnia, v.34, p.987-996, 2005.

BERCHIELLI, T.T.; RODRIGUEZ, N.M.; OLIVEIRA, H.P. Efeito de diferentes relações volumoso:concentrado no consumo, digestibilidade e partição da digestão de dietas de bovinos. Arquivo Brasileiro de Medicina Veterinária e Zootecnia, v.48, p.607-617, 1996a.

BERCHIELLI, T.T.; RODRIGUEZ, N.M.; ANDRADE, P. Concentração, proporção molar e taxa de produção de ácidos graxos voláteis (AGV) no rúmen de bovinos alimentados com diferentes níveis de concentrado na dieta. Revista da Sociedade Brasileira de Zootecnia, v.25, p.511-521, 1996 b.

BLAXTER, K.L.; CLAPPERTON, J.L. Prediction of the amount of methane produced by ruminants. British Journal of Nutrition, v.19, p.511-522, 1965.

CARDOSO, R.C.; VALADARES FILHO, S.C.; COELHO DA SILVA, J.F. Consumo e digestibilidades aparentes totais e parciais de rações contendo diferentes níveis de concentrado, em novilhos F1 Limousin x Nelore. Revista Brasileira de Zootecnia, v.29, p.1832-1843, 2000.

CHANEY,A.L.; MARBACH, E.P. Modified reagents for determination of urea and ammonia. Clinical Chemistry, v.8, p.130-137, 1962.

CHRISTOPHERSEN, C.T.; WRIGHT, A.D.G.; VERCOE, P.E. In vitro methane emissions and acetate:propionate ratio are decreased when artificial stimulation of the rumen wall is combined with increasing grain diets in sheep. Journal of Animal Science, v.86, p.384-389, 2008.

DEHORITY, B.A.; ORPIN, C.G. Development of, and natural fluctuations in, rumen microbial populations. In: HOBSON, P.N. (Ed.) The rumen microbial ecosystem. New York: Elsevier, 1988. p.151-183.

EUN, J.S.; FELLNER, V.; BURNS, J.C. Fermentation of eastern gamagrass (Tripsacum dactyloides [L.] L.) by mixed cultures of ruminal microorganisms with or without supplemental corn. Journal of Animal Science, v.82, p.170-178, 2004.

FU, C.J.; FELTON, E.E.; LEHMKUHLEI, J.W. et al. Ruminal peptide concentration to optimize microbial growth and efficiency. Journal of Animal Science, v.79, p.1305- 1312, 2001.

GIGER-REVERDIN, S.; SAUVANT, D. Methane production in sheep in relation to concentrate feed composition from bibliographic data. In: LEDIN, I.; MORAND-FEHR, P. (Eds.) Sheep and goat nutrition: Intake, digestion, quality of products and rangelands Zaragoza. Zaragoza: Ciheam-Iamz, 2000. p.43-46.

HUHTANEN, P. The effects of barley vs. barley fiber with or without distiller's solubles on site and extent of nutrient digestion in cattle fed grass-silage-based diet. Animal Feed Science and Technology, v.36, p.319-337, 1993.

INTERGOVERNMENTAL PANEL ON CLIMATE CHANGE IPCC. 2007. Climate change 2007: the physical science basis. Contribution of Working Group I to the Fourth Assessment Report of the Intergovernmental Panel on Climate Change. Available at: $<$ http://ipcc-wg1.ucar.edu/wg1/docs/WG1AR4_SPM_Approved 05Feb.pdf.> Accessed on: Jul. 15, 2008.

JOHNSON, D.E.; JOHNSON, K.A. Recent developments in understanding enteric methane production by ruminants: Implications for mitigation. In: International Non-CO2 GHG Mitigation Workshop. Washington, D.C., 2002.

JOHNSON, K.A.; HUYLER, M.; WESTBERG, H. et al. Measurement of methane emissionss from ruminant livestock using a $\mathrm{SF}_{6}$ tracer technique. Environmental Science and Technology, v.28, p.359-362, 1994. 
JOHNSON, K.A.; JOHNSON, D.E. Methane emissionss from cattle. Journal of Animal Science, v.73, p.2483-2492, 1995.

KOSTER, H.H.; COCHRAN, R.C.; TITGEMEYER, E.C. Effect of increasing degradable intake protein on intake and digestion of low quality, tallgraass-praire roughage by beef cows. Journal of Animal Science, v.74, p.2473-2481, 1996.

KRYSL, L.J.; GALYEAN, M.L.; ESTELL, R.E. et al. Estimating digestibility and faecal output in lambs using internal and external markers. Journal of Agricultural Science, v.111, p.19-25, 1988.

LEVENTINI, M.W.; HUNT, C.W.; ROFFLER, R.E. Effect of dietary level of barley-based supplements and ruminal buffer on digestion and growth by beef cattle. Journal of Animal Science, v.68, p.4334-4344, 1990.

LITTELL, R.C.; MILLIKEN, G.A.; STROUP, W.W. SAS ${ }^{\circledR}$ system for mixed models. Cary: 1996. 633p.

MATSUYAMA, H.; HORIGUCHI, K.; TAKAHASHI, T. et al. Control of methane production from expiratory gas by ruminal dosing with mechanical stimulating goods in holstein steer. In: Proceedings 9th Congr. Asian-Australasian Association of Animal Production Societies and 23rd Biennial Conf. Australian Society of Animal Production, Sydney, Australia. Asian-Australasian Journal of Animal Science, Seoul, Korea, 2000. p.215.

MIZUBUTI, I.Y.; RIBEIRO, E.L.A.; ROCHA, M.A. Consumo e digestibilidade aparente das silagens de milho (Zea mays L.), sorgo (Sorghum bicolor (L.) Moench) e girassol (Helianthus annuus L.). Revista Brasileira de Zootecnia, v.31, p.267-272, 2002.

MOSS, A.R.; GIVENS, D.I.; GARNSWORTHY, P.C. The effect of supplementing grass silage with barley on digestibility, in sacco degradability, rumen fermentation and methane production in sheep at two levels of intake. Animal Feed Science and Technology, v.55, p.9-33, 1995.

O'HARA, P.; FRENEY, J.; ULYATT, M. Abatement of agricultural non-carbon dioxide greenhouse gas emissionss: a study of research requirements. Report prepared for the Ministry of Agriculture and Forestry on Behalf of the Convenor, Ministerial Group on Climate Change, the Minister of Agriculture and the Primary Industries Council. New Zealand: Crown Copyright Ministry of Agriculture and Forestry, 2003. 170p. Available at: $<$ www.maf.govt.nz/publications> Accessed on: Nov. 12, 2006.

OLIVEIRA, S.G.; BERCHIELLI, T.T.; PEDREIRA, M.S. et al. Effect of tannin levels in sorghum silage and concentrate supplementation on apparent digestibility and methane emissions in beef cattle. Animal Feed Science and Technology, v.135, p.236-248, 2007.

PRIMAVESI, O.; FRIGHETTO, R.T.S.; PEDREIRA, M.S. et al. Técnica do gás traçador SF6 para medição de campo do metano ruminal em bovinos: adaptações para o Brasil. São Carlos: Embrapa Pecuária Sudeste, 2004. 76p. (Embrapa Pecuária Sudeste, Documentos, 39). Available at: <http://www.cppse. embrapa.br/080servicos/070publicacaogratuita/documentos/ Documento39.pdf.> Accessed on: Oct. 10, 2007.

VAN SOEST, P.J.; ROBERTSON, J.B.; LEWIS, B.A. Methods for dietary fiber, neutral detergent fiber, and nonstarch polysaccharides in relation to animal nutrition. Journal of Dairy Science, v.74, p.3583-3597, 1991.

WESTBERG, H.H.; JOHNSON, K.A.; COSSALMAN, M.W. et al. A SF6 tracer technique: methane measurement from ruminants. Report, Revision 2. Pullman-Washington: Washington State University, 1998. 40p. 